\title{
A Systematic Review : Well-being Therapy
}

\author{
Venty Ratnasari Telaumbanua \\ Magister Psikologi Profesi, Fakultas Psikologi Universitas Surabaya \\ ventyratna@gmail.com
}

Ananta Yudiharso

Fakultas Psikologi, Universitas Surabaya

ananta@staff.ubaya.ac.id

\begin{abstract}
Well-being therapy is one of the relatively new interventions that used to achieve optimal and balanced functioning in certain dimensions of the individual. The aim of this study is to determine the effectiveness of well-being therapy applied in several contexts and in different age categories. Review was conducted in 14 studies based on inclusion and exclusion criterias. The results of the review indicate that well-being therapy can be carried out in the adult and student age categories, affective disorder and addiction cases, as well as preventive and curative treatments. Well-being therapy will also achieve maximum results if combined with with CBT treatment. However, there also need to consider about the number of sessions and the duration, and the severity of individual disorders so that the client can follow all the therapeutic process.
\end{abstract}

Keywords : well-being therapy; WBT.

\begin{abstract}
Abstrak
Well-being therapy adalah salah satu intervensi yang tergolong baru dan digunakan untuk mencapai keberfungsian secara optimal dan seimbang pada dimensi tertentu pada diri individu. Tujuan penelitian ini yakni untuk mengetahui efektivitas dari well-being therapy mengingat banyaknya penerapan intervensi pada beberapa konteks serta dalam kategori usia yang berbeda-beda. Review dilakukan pada 14 jurnal berdasarkan kriteria inklusi dan eksklusi yang sudah ditetapkan sebelumnya. Hasil review menunjukkan bahwa well-being therapy dapat dilakukan pada kategori usia dewasa maupun pelajar, kasus affective disorder maupun addiction, serta penanganan preventif maupun kuratif. Pemberian well-being therapy juga akan semakin mencapai hasil maksimal jika dipadukan dengan penanganan dengan CBT. Akan tetapi perlu menjadi pertimbangan juga berkaitan dengan jumlah sesi dan durasi, serta tingkat keparahan gangguan individu agar dapat mengikuti proses terapi secara maksimal.
\end{abstract}

Kata kunci: well-being therapy; WBT. 


\section{Pendahuluan}

Well-being therapy (WBT) merupakan sebuah terapi yang dikembangkan dari konsep psychological well-being (PWB) dari Ryff. PWB sendiri meliputi enam dimensi yakni autonomy, environmental mastery, personal growth, purpose in life, self-acceptance and positive interpersonal relationships (Ryff, 1989). Well- being therapy merupakan salah satu pengembangan dari psikologi positif yang berusaha untuk meningkatkan aspek positif serta mengembangkan kekuatan yang dimiliki indiviu tanpa menekankan pada aspek negatif individu tersebut. Tujuan dari terapi ini adalah untuk meningkatkan tingkat kesejahteraan psikologis dan keberfungsian dari individu sehingga menjadi optimal melalui dimensidimensi yang dikemukakan oleh Ryff (Ruini, 2014). Terapi ini merupakan terapi jangka pendek dan mengembangkan strategi terapeutik (Fava, 1999).

Well-being therapy merupakan sebuah program terapi yang terstruktur yang terdiri dari 8-12 sesi. Sesi-sesi tersebut terdiri dari beberapa tahapan yakni tahapan inisiasi, tahapan intermediasi dan tahapan akhir. Fase awal berkaitan dengan pengamatan diri terhadap kesejahteraan psikologis. Kemudian pasien didorong untuk mengidentifikasi pikiran, kepercayaan, dan perilaku yang mengarah pada gangguan kesejahteraan dini (fase menengah). Bagian terakhir melibatkan restrukturisasi kognitif dimensi disfungsional kesejahteraan psikologis dan memenuhi tantangan yang mungkin melibatkan pengalaman optimal (Guidi, Rafanelli \& Fava, 2018). Well-being therapy juga bersifat mengarahkan dan berfokus pada masalah yang dialami oleh individu. Setiap sesi dari well-being therapy memiliki durasi sekitar 30-50 menit. Penekanan utama pada terapi ini adalah observasi diri dan juga interaksi antara individu dengan terapis (Fava, 1999).

Fava et al. (2001) memberi penekanan bahwa intervensi ini dipilih berdasarkan penerapannya yang mudah dilaksanakan pada populasi klinis. Akan tetapi setiap individu memiliki kombinasi kekuatan ataupun kerentanan yang berbeda-beda untuk diarahkan dan dapat berfungsi secara optimal. Hal ini dapat berbeda setiap orangnya tergantung dari kemampuan untuk menilai diri secara 
positif berbeda-beda dan dari konteks dari individu tersebut. Guidi, Rafanelli \& Fava (2018) menjelaskan bahwa keseimbangan optimal ini dapat berbeda dari individu ke individu, sesuai dengan faktor-faktor seperti sifat kepribadian, peran sosial, dan konteks budaya dan sosial.

Semakin banyaknya penelitian yang menggunakan intervensi well-being therapy dan juga semakin beragamnya konteks penelitian serta karakteristik dari individu yang diteliti menghasilkan efektivitas terapi yang berbeda-beda. Tak hanya itu, pengaplikasian well-being therapy berdasarkan jumlah sesi yang dilakukan di lapangan dapat berdampak pada efektivitas terapi. Hal ini didukung oleh Guidi, Rafanelli \& Fava (2018) yang menyatakan bahwa walaupun sudah diuji dengan cara yang terkontrol, aplikasi klinis dari well-being therapy masih belum banyak diselidiki serta area pengembangan potensial berhubungan dengan pelaksanaan intervensi (misalnya individu, kelompok, berorientasi keluarga, dan bantuan komputer), serta bidang-bidang baru penerapan WBT, seperti tindakan pencegahan terutama pada masa kanak-kanak dan remaja dan psikoterapi dalam pengaturan penyakit medis belum banyak diketahui.

\section{Metode}

\section{Sumber Informasi dan Kriteria Pencarian}

Sumber data didapatkan dari berbagai data base, yakni Elsevier, Springer Science, Psychoter Psychosom, IJPS, IJBPAS, IDOSI Publications, dan IJIR. Kata kunci yang digunakan dalam pencarian adalah "well-being therapy", "wellbeing therapy in psychology", "WBT", Pencarian dilakukan pada April 2019 dan didapatkan 47 hasil berdasarkan pencarian pada kata kunci tersebut. Kemudian setelah membaca judul dan juga abstrak dengan mencocokkan pada kriteria inklusi didapatkan 22 jurnal. Setelah membaca penelitian secara lengkap dan berdasarkan kriteria eksklusi didapatkan 14 jurnal. Proses pemilihan jurnal ditunjukkan pada gambar 1.

Penemuan menggunakan kata kunci $(n=47)$

Tereliminasi $(\mathrm{N}=25)$ 


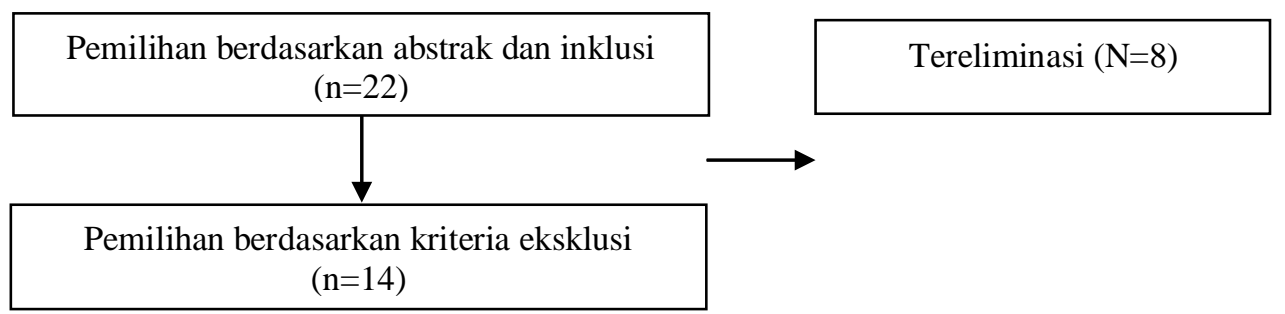

Gambar 1. Proses pemilihan jurnal dan eliminasi berdasarkan kriteria inklusi dan eksklusi.

\section{Kriteria inklusi dan eksklusi}

Kajian ini mencakup studi yang memenuhi kriteria inklusi sebagai berikut :

a. Penelitian eksperimen

b. Memiliki kelompok pembanding

c. Jurnal ditulis dalam Bahasa Inggris atau diterjemahkan dalam Bahasa Inggris

Sementara untuk kriteria eksklusi yakni :

a. Dimulai sejak 2005

b. Menghindari studi literatur

\section{Kodifikasi hasil dan analisis informasi}

Informasi berikut dikumpulkan untuk masing-masing studi yang termasuk dalam tinjauan ini: penulis dan tahun publikasi, konteks sampel yang digunakan, rentang/rata-rata usia partisipan, pengukuran hasil variabel sebelum dan sesudah treatment, jumlah sesi dan durasi per minggu, perlakuan pada kelompok kontrol, total sampel, hasil penelitian.

\section{Hasil}

Hasil dari pemilihan jurnal berdasarkan kriteria inklusi dan eksklusi didapatkan 14 jurnal. Dari 14 jurnal tersebut melibatkan 1127 partisipan dan dapat dikategorikan berdasarkan umur, konteks penelitian, tujuan penelitian, jumlah sesi dan durasi serta hasil dari intervensi yang diberikan. Untuk data dari 14 jurnal dapat dilihat pada Tabel 1.

\section{Usia}

Berdasarkan usia dari sampel dapat dilihat bahwa usia sampel terbagi atas 
2 kelompok utama yakni usia pelajar $(n=3$ penelitian) dengan usia dewasa $(n=6$ penelitian) dan lainnya tidak disebutkan ( $\mathrm{n}=5$ penelitian). Pada kategori ini didapatkan hasil bahwa well-being therapy dapat digunakan pada kelompok usia tersebut dan mendapatkan hasil yang efektif.

\section{Konteks Penelitian}

Terdapat beberapa konteks permasalahan yang ditangani dalam studi-studi tersebut yang dibagi atas beberapa jenis yakni gangguan afek ( $\mathrm{n}$ penelitian $=6$ ), adiksi ( $\mathrm{n}=4$ penelitian), gangguan kecemasan $(\mathrm{n}=1$ penelitian), serta permasalahan well-being ( $\mathrm{n}=3$ penelitian). Dari beberapa jenis gangguan tersebut sebagian besar dapat ditangani dengan menggunakan well-being therapy.

\section{Tujuan Penelitian}

Tujuan dari berbagai studi tersebut terbagi dua yakni studi untuk mengintervensi sebuah permasalahan/kuratif $(n=11$ penelitian $)$ dan mencegah atau mempromosikan kesejahteraan individu/preventif ( $n=3$ penelitian). Hasil yang didapatkan juga menunjukkan bahwa well-being therapy dapat digunakan dalam penanganan kuratif maupun preventif.

\section{Jumlah Sesi dan Durasi}

Jumlah sesi yang digunakan cukup bervariasi mulai dari 4 sesi $(n=2$ penelitian), 6 sesi $(\mathrm{n}=2$ penelitian), 8 sesi $(\mathrm{n}=3$ penelitian), 10 sesi $(\mathrm{n}=1$ penelitian), 11 sesi $(n=1$ penelitian), 12 sesi $(n=3$ penelitian), 14 sesi $(n=1$ penelitian), 16 sesi ( $n=1$ penelitian). Sebagian besar menunjukkan hasil yang efektif kecuali pada penelitian yang menggunakan 4 sesi (tidak terdapat hasil yang signifikan antara WBT dan SQ) dan pada salah satu penelitian yang menggunakan 12 sesi (tidak ada hasil yang signifikan antara WBT dengan psikopatologi maupun dengan kebahagiaan).

\section{Intervensi}

Dari 14 penelitian, terdapat 10 penelitian yang hanya menggunakan intervensi WBT, 3 penelitian yang menggunakan intervensi WBT yang dikombinasikan dengan CBT serta 1 penelitian yang dikombinasikan dengan CBT dan medication management. Hasilnya menunjukkan bahwa pelaksanaan intervensi antara CBT dan WBT secara bergantian menghasilkan perubahan yang 
drastis pada pasien cyclothimic disorder.

\section{Hasil Intervensi}

Dari hasil yang didapatkan bahwa terdapat 12 penelitian yang memiliki pengaruh pada variabel penelitian sementara ada 2 penelitian yang menyatakan bahwa WBT tidak memiliki pengaruh pada penurunan psikopatologi dan juga untuk meningkatkan kebahagiaan dan tidak ada perbedaan antara well-being therapy dengan positive therapy. Pada penelitian tersebut dijelaskan bahwa pada pasien yang sudah mengalami gangguan memori karena efek dari zat-zat tertentu terlebih pengaplikasian well-being therapy menggunakan kertas dan pena memiliki pengaruh pada hasil intervensi.

Tabel 1. Hasil Review Well-Being Therapy

\begin{tabular}{|c|c|c|c|c|c|c|c|c|c|c|}
\hline $\begin{array}{c}\text { Penulis } \\
\text { pertama, } \\
\text { tahun }\end{array}$ & $\begin{array}{l}\text { Karakter- } \\
\text { istik ampel }\end{array}$ & $\begin{array}{c}\text { Usia } \\
\text { (rentang } \\
\text { / rata- rata) }\end{array}$ & Alat Ukur & Intervensi & $\begin{array}{l}\text { Jumlah } \\
\text { sesi/ } \\
\text { durasi }\end{array}$ & $\begin{array}{c}\text { Kelompok } \\
\text { kontrol }\end{array}$ & $\begin{array}{c}\text { Total } \\
\text { sampel }\end{array}$ & Hasil & Kesimpulan & Hasil \\
\hline Fava, 2005 & $\begin{array}{l}\text { Pasien } \\
\text { dengan } \\
\text { GAD }\end{array}$ & n.m & $\begin{array}{l}\text { The CID } \\
\text { Anxiety Scale, } \\
\text { PWB Scales, } \\
\text { SQ }\end{array}$ & $\begin{array}{l}\text { Kombinasi } \\
\text { CBTdan WBT }\end{array}$ & $\begin{array}{c}8 \text { sesi }(4 \\
\text { sesi CBT } \\
\text { dan } 4 \text { sesi } \\
\text { WBT }\end{array}$ & Hanya CBT & $\begin{array}{c}20(\mathrm{EG}= \\
10 ; \mathrm{CG}= \\
10)\end{array}$ & $\begin{array}{l}\text { Ada hasil yang } \\
\text { signifikan dari } \\
\text { intervensi dengan } \\
\text { kombinasi CBT dan } \\
\text { WBT pada tingkat } \\
\text { kecemasan } \\
\text { dibandingkan hanya } \\
\text { dengan CBT saja } \\
(p=0,007)\end{array}$ & $\begin{array}{l}\text { WBTdapat } \\
\text { digunakan dalam } \\
\text { penanganan } \\
\text { GAD }\end{array}$ & + \\
\hline Fava, 2011 & $\begin{array}{l}\text { Pasien } \\
\text { dengan } \\
\text { gangguan } \\
\text { siklotimik }\end{array}$ & $\begin{array}{l}18-65 \\
\text { tahun }\end{array}$ & $\begin{array}{l}\text { Modified CID, } \\
\text { MAS }\end{array}$ & $\begin{array}{l}\text { Kombinasi } \\
\text { CBTdan WBT }\end{array}$ & $\begin{array}{l}10 \text { sesi / } \\
45 \text { menit }\end{array}$ & $\mathrm{CM}$ & $\begin{array}{c}62 \\
(E G=31 \\
C G=31)\end{array}$ & $\begin{array}{l}\text { Ada perbedaan } \\
\text { signifikan yang } \\
\text { ditemukan dalam } \\
\text { pengukuran hasil } \\
\text { gangguan afek setelah } \\
\text { intervensi CBT-WBT } \\
\text { dibandingkan dengan } \\
\text { kelompok CM (total } \\
\text { skor CID, F = 11.824; } \\
\text { df = 1.59; } \mathrm{p}=0.002 ; \\
\text { post skor MAS, F = } \\
25.989 ; \mathrm{df}=3.58 ; \mathrm{p}= \\
0.001)\end{array}$ & $\begin{array}{l}\text { Kombinasi } \\
\text { antara CBT dan } \\
\text { WBT memiliki } \\
\text { efek } \\
\text { besar }\end{array}$ & + \\
\hline $\begin{array}{l}\text { Kennard, } \\
2014\end{array}$ & $\begin{array}{l}\text { Anak dan } \\
\text { remaja } \\
\text { dengan } \\
\text { depresi akut }\end{array}$ & $\begin{array}{c}8-17 \\
\text { tahun }\end{array}$ & $\begin{array}{l}\text { Children's } \\
\text { Depression } \\
\text { Rating Scale- } \\
\text { Revised } \\
\text { [CDRS-R]) }\end{array}$ & \begin{tabular}{|l} 
Kombinasi \\
CBT, \\
medication \\
management \\
dan WBT
\end{tabular} & $\begin{array}{l}11 \text { sesi / } \\
60 \text { menit }\end{array}$ & $\begin{array}{c}\text { Medication } \\
\text { manage- } \\
\text { ment } \text { saja }\end{array}$ & $\begin{array}{c}144 \\
(E G=75 \\
C G=69)\end{array}$ & $\begin{array}{l}\text { Intervensi } \\
\text { management } \\
0,31,95 \% \mathrm{CI}=0,13 \\
0,75)\end{array}$ & $\begin{array}{l}\text { CBT dan WBT } \\
\text { efektif dalam } \\
\text { mengurangi } \\
\text { risiko kambuh } \\
\text { pada } \\
\text { anak-anak dan } \\
\text { remaja dengan } \\
\text { gangguan } \\
\text { depresi mayor. }\end{array}$ & + \\
\hline $\begin{array}{l}\text { Moeeniza } \\
\text { deh, } 2010\end{array}$ & $\begin{array}{l}\text { Pasien depresi } \\
\text { (remaja dan } \\
\text { pelajar) }\end{array}$ & $20-40$ & $\begin{array}{l}\text { PWBS, } \\
\text { BDI- II, } \\
\text { Rorschach } \\
\text { Inkblot } \\
\text { Test }\end{array}$ & WBT & $\begin{array}{l}8 \text { sesi/ } 45 \\
\text { menit }\end{array}$ & CBT & $\begin{array}{c}40 \\
(E G=20 \\
C G=20)\end{array}$ & $\begin{array}{l}\text { Ada perbedaan skor } \\
\text { yang signifikan untuk } \\
\text { kelompok CBT (Mean } \\
\text { of pre }=219.20, \text { dan } \\
\text { post } \\
=366.35) \text { dan } \\
\text { kelompok WBT (Mean } \\
\text { of pre }=187, \text { post }= \\
449.85), \text { nilai F } \\
\end{array}$ & $\begin{array}{l}\text { WBTefektif } \\
\text { digunakan untuk } \\
\text { mengurangi } \\
\text { depresi }\end{array}$ & + \\
\hline
\end{tabular}




\begin{tabular}{|c|c|c|c|c|c|c|c|c|c|c|}
\hline & & & & & & & & $\begin{array}{l}(7258.937) \text { dan } \\
\text { nilai } \mathrm{p}(0,001)\end{array}$ & & \\
\hline $\begin{array}{l}\text { Moeeniza } \\
\text { deh, } 2010\end{array}$ & $\begin{array}{l}\text { Pasien remaja } \\
\text { dan pelajar } \\
\text { dewasa } \\
\text { dengan MDD }\end{array}$ & n.m. & $\begin{array}{l}\text { BDI-II, } \\
\text { PWBS, } \\
\text { Rorschach } \\
\text { Inkblot Test }\end{array}$ & WBT & $\begin{array}{l}8 \text { sesi / } 45- \\
60 \text { menit }\end{array}$ & CBT & $\begin{array}{c}40 \\
(E G=20 ; \\
C G=20)\end{array}$ & $\begin{array}{l}\text { Perbedaan signifikan } \\
\text { dari skor depresi dalam } \\
\text { CBT (rata-rata pre }= \\
33,00 ; \text { post }=12,35 \text { ) } \\
\text { dan WBT (rata-rata } \text { pre } \\
=45,35 ; \text { post }=12,35 \text { ) }\end{array}$ & $\begin{array}{l}\text { WBT lebih } \\
\text { efektif daripada } \\
\text { CBT }\end{array}$ & + \\
\hline $\begin{array}{l}\text { Moeeniza } \\
\text { deh, } 2017\end{array}$ & $\begin{array}{l}\text { Wanita tidak } \\
\text { subur }\end{array}$ & $20-40$ & $\begin{array}{l}\text { PWB dan } \\
\text { DASS-21 }\end{array}$ & WBT & $\begin{array}{l}8 \text { sesi } / 45- \\
60 \text { menit }\end{array}$ & $\begin{array}{l}\text { Masuk } \\
\text { daftar } \\
\text { tunggu }\end{array}$ & $\begin{array}{c}22 \\
(E G=11 ; \\
C G=11)\end{array}$ & $\begin{array}{l}\text { Perbedaan signifikan } \\
\text { skor depresi pada EG } \\
\text { ( } \text { mean of pre }=20,90 ; \\
\text { mean of post }=7,27) \\
\text { dan CG }(\text { mean of pre }= \\
21,09 ; \text { mean } \\
\text { of post }=23,09)\end{array}$ & \begin{tabular}{|l|} 
WBTefektif \\
digunakan untuk \\
menurunkan \\
depresi
\end{tabular} & + \\
\hline $\begin{array}{l}\text { Pirnia, } \\
2015\end{array}$ & $\begin{array}{l}\text { Pasien pria dan } \\
\text { wanita } \\
\text { bergantung } \\
\text { pada } \\
\text { metamfeta min }\end{array}$ & $25-45$ & $\begin{array}{l}\text { SCID DSM } \\
\text { IV; DASS- } \\
21\end{array}$ & WBT & $\begin{array}{c}12 \text { sesi / } 50 \\
\text { menit }\end{array}$ & n.m. & $\begin{array}{c}40 \\
(E G=20 \\
C G=20)\end{array}$ & \begin{tabular}{|l|} 
Terdapat penurunan \\
tingkat kecemasan \\
(mean of pre $=22,95 ;$ \\
mean of post $=15,65)$ \\
dan stres (mean of \\
pre $=18,70 ;$ mean of \\
post $=13,45$ begitu juga \\
dengan tingkat \\
depresi (mean of \\
pre $=14,10 ;$ mean of \\
post $=10,95)$ \\
\end{tabular} & $\begin{array}{l}\text { WBT memiliki } \\
\text { efek signifikan } \\
\text { pada kecemasan } \\
\text { dan stres tetapi } \\
\text { tidak signifikan } \\
\text { pada depresi }\end{array}$ & + \\
\hline $\begin{array}{l}\text { Pirnia, } \\
2015\end{array}$ & $\begin{array}{l}\text { Pasien yang } \\
\text { mengikuti } \\
\text { terapi } \\
\text { metadon }\end{array}$ & $20-50$ & $\begin{array}{l}\text { SCID-DSM IV; } \\
\text { DRI }\end{array}$ & WBT; PPT & $14 / 60$ & n.m. & $\begin{array}{c}39 \\
(\mathrm{WBT}=12 ; \\
\mathrm{PPT}=12 ; \mathrm{C} \\
\mathrm{G}=12)\end{array}$ & \begin{tabular}{|l|} 
Tidak ada perbedaan \\
yang signifikan antara \\
PPT dan WBT \\
$(p=0,208)$, tetapi PPT \\
dan CG $(p<0,0001)$ dan \\
WBT dan CG \\
$(p=0,002)$ memiliki \\
perbedaan yang \\
signifikan dalam sikap \\
mereka terhadap obat.
\end{tabular} & $\begin{array}{l}\text { Baik PPT dan } \\
\text { WBT efektif } \\
\text { dalam } \\
\text { meningkatkan } \\
\text { sikap terhadap } \\
\text { obat }\end{array}$ & - \\
\hline $\begin{array}{l}\text { Pirnia, } \\
2016\end{array}$ & $\begin{array}{l}\text { Pasien yang } \\
\text { dirujuk ke pusat } \\
\text { perawatan } \\
\text { kecanduan }\end{array}$ & $18-31$ & $\begin{array}{l}\text { SCID DSM } \\
\text { IV; } \\
\text { Question- } \\
\text { naire } \\
\text { skills }\end{array}$ & WBT & $\begin{array}{l}12 \underset{\text { kali }}{\text { (dua }} \\
\text { seminggu } \\
\cos ^{/} 50 \\
\text { menit }\end{array}$ & $\begin{array}{c}\text { Hanya } \\
\text { pemeriksaan } \\
\text { medis }\end{array}$ & $\begin{array}{c}34 \\
(\mathrm{EG}=17 ; \\
\mathrm{CG}=17)\end{array}$ & $\begin{array}{l}\text { WBT memiliki efek } \\
\text { signifikan }(p<0,05) \\
\text { pada peningkatan } \\
\text { keterampilan }\end{array}$ & \begin{tabular}{|l|} 
WBT efektif \\
digunakan untuk \\
meningkatkan \\
keterampilan \\
penggunaan \\
kondom pada \\
penderita \\
ketergantungan \\
kokain. \\
\end{tabular} & + \\
\hline $\begin{array}{l}\text { Pirnia, } \\
2016\end{array}$ & $\begin{array}{l}\text { Laki-laki } \\
\text { ketergantu ngan } \\
\text { metam- fetamin }\end{array}$ & n.m. & $\begin{array}{l}\text { MHC-LF; OQ- } \\
45 ; \mathrm{OHQ}\end{array}$ & WBT & $\begin{array}{c}12 \text { sesi / } 50 \\
\text { menit }\end{array}$ & n.m. & $\begin{array}{c}6 \\
(E G=3 ; \\
C G=3)\end{array}$ & $\begin{array}{l}\text { Tidak terdapat hasil } \\
\text { yang signifikan }\end{array}$ & $\begin{array}{l}\text { WBT tidak } \\
\text { mengurangi } \\
\text { psikopatologi } \\
\text { dan } \\
\text { meningkatkan } \\
\text { kebahagiaan. } \\
\end{array}$ & - \\
\hline Ruini, 2006 & $\begin{array}{l}\text { liswa sekolah } \\
\text { menengah }\end{array}$ & n.m. & $\begin{array}{l}\text { KSQ and } \\
\text { PWBS }\end{array}$ & $\begin{array}{l}\text { WBT- } \\
\text { school } \\
\text { based } \\
\text { interventio } \\
n\end{array}$ & 4 sesi/ 2 jam & $\left|\begin{array}{l}\text { CBT } \\
\text { school based } \\
\text { intervention }\end{array}\right|$ & $\begin{array}{c}111 \\
(E G=57 ; \\
C G=54)\end{array}$ & $\begin{array}{l}\text { CBT signifikan untuk } \\
\text { meningkatkan } \mathrm{PWB} \\
(p=0,001) \text { dan } \mathrm{SQ}(\mathrm{p}= \\
0,001) \\
\text { WBT signifikan untuk } \\
\text { PWB }(p=0,012) \text { tetapi } \\
\text { tidak untuk SQ }\end{array}$ & $\begin{array}{l}\text { Baik } \\
\text { maupun } \\
\text { efektif } \\
\text { kesejahteraan } \\
\text { psikologis }\end{array}$ & + \\
\hline Ruini, 200 & $\begin{array}{l}\text { Siswa SMA } \\
\text { tahun pertama }\end{array}$ & $\begin{array}{c}14.4 \\
\text { tahun }\end{array}$ & $\begin{array}{l}\text { PWBS, KSQ, } \\
\text { RCMAS }\end{array}$ & $\begin{array}{l}\text { WBT school } \\
\text { intervention }\end{array}$ & $6 \mathrm{sesi} / 2 \mathrm{jam}$ & \begin{tabular}{|} 
Attention- \\
placebo \\
school \\
intervention
\end{tabular} & $\begin{array}{c}227(\mathrm{EG}= \\
5 \text { kelas; } \\
\mathrm{CG}=4 \\
\text { kelas })\end{array}$ & \begin{tabular}{|l|} 
Ada peningkatan \\
signifikan skor total \\
PWB $(p=0,048)$, \\
kesejahteraan fisik (SQ) \\
$(p=0,007)$, kecemasan \\
$(\mathrm{SQ})(p=0,026)$, \\
somatisasi (SQ) \\
$(p=0,004)$.
\end{tabular} & $\left|\begin{array}{l}\text { WBT efektif } \\
\text { dalam } \\
\text { mempromosikan } \\
\text { emosi positif dan } \\
\text { kesejahteraan }\end{array}\right|$ & + \\
\hline
\end{tabular}




\begin{tabular}{|c|c|c|c|c|c|c|c|c|c|c|}
\hline $\begin{array}{c}\text { Stangier, } \\
2013\end{array}$ & Pasien MDD & n.m & $\begin{array}{l}\text { Longitudinal } \\
\text { Interval } \\
\text { Follow-Up } \\
\text { Evaluation } \\
\text { (LIFE), The } \\
\text { 17-item } \\
\text { HAM-D }\end{array}$ & $\begin{array}{l}\text { CBT dan } \\
\text { WBT }\end{array}$ & $\begin{array}{c}16 \text { sesi / } 20 \\
\text { menit }\end{array}$ & $\begin{array}{c}\text { Manualized } \\
\text { psycho- } \\
\text { education }\end{array}$ & $\begin{array}{c}180(\mathrm{EG} \\
=90 ; \mathrm{CG} \\
=90)\end{array}$ & \begin{tabular}{|l|} 
Analisis regresi \\
menggunakan Cox \\
menunjukkan tidak ada \\
perbedaan signifikan \\
antara dua perlakuan \\
namun terdapat \\
perbedaan signifikan \\
dari hasil observasi \\
antara pasien yang \\
mengikuti kurang dari \\
lima sesi dan yang \\
mengikuti lebih dari \\
lima sesi yakni \\
kecenderungan \\
kekambuhan yang lebih \\
kurang pada individu \\
yang mengikuti lebih \\
dari 5 sesi. \\
\end{tabular} & $\begin{array}{l}\text { Penanganan } \\
\text { dengan } \\
\text { pendekatan CBT } \\
\text { dan WBT } \\
\text { memiliki } \\
\text { signifikan } \\
\text { risiko tinggi } \\
\text { kekambuhan } \\
\text { depresi. }\end{array}$ & + \\
\hline $\begin{array}{l}\text { Tomba, } \\
2010\end{array}$ & $\begin{array}{l}\text { Siswa sekolah } \\
\text { menengah }\end{array}$ & 11.41 & $\begin{array}{l}\text { KSQ, PWB, } \\
\text { RCMAS }\end{array}$ & WBT & $6 \mathrm{sesi} / 2 \mathrm{jam}$ & $\begin{array}{c}\text { Anxiety- } \\
\text { manage- } \\
\text { ment }\end{array}$ & $\begin{array}{c}162 \\
(\mathrm{EG}=4 \\
\text { kelas } ; \mathrm{CG} \\
=4 \text { kelas })\end{array}$ & \begin{tabular}{|l|} 
AM menunjukkan \\
penurunan yang \\
signifikan pada \\
kecemasan $\mathrm{SQ}(\mathrm{F}=$ \\
5,$25 ; \mathrm{df}=1,152 ; \mathrm{p}=$ \\
$0,02)$ dibandingkan \\
WBT. \\
WBT menunjukkan \\
efek positif pada \\
wellbeing $\mathrm{SQ}$, \\
friendliness $(\mathrm{F}=4,20 ;$ \\
$\mathrm{df}=1,152 ; \mathrm{p}=0,04)$ \\
Tidak ada perbedaan \\
signifikan antara WBT \\
dan AM pada RCMAS.
\end{tabular} & $\begin{array}{l}\text { WBT dapat } \\
\text { meningkatkan } \\
\text { kesejahteraan } \\
\text { siswa. }\end{array}$ & + \\
\hline
\end{tabular}

$A M=$ Anxiety Management $; B D I=$ Beck Depression Inventory; $C B T=$ Cognitive Behavioral Therapy; $C I D=$ Clinical Interview of Depression; $C M=$ Clinical Management $;$ DASS = Depression, Anxiety and Stress Scale; DRI = Drug Attitude Inventory; EG = Experimental Group; $C G=$ Control Group; $G A D=$ General Anxiety Disorder; HAM = Hamilton Depression Rating Scale; KSQ = Kellner's Symptom Questionnaire; MAS = The Mania Scale; MHC-LF = Mental Health Continuum-Long Form; n.m. = Not Mention; $P P T=$ Positive Psychotherapy; $P W B S=$ Psychological Well-Being Scale; OHQ = Oxford Happiness Questionnaire; OQ= Outcome Questionnaire; RCMAS = Revised Children's Manifest Anxiety Scale; SCID-DSM IV = Structured Clinical Interview for Disorders DSM IV; WBT = Well- Being Therapy.

\section{Pembahasan}

Hasil ulasan dari beberapa penelitian menunjukkan hasil yang positif yakni dari 14 jurnal terdapat 12 penelitian menyatakan bahwa well-being therapy dapat meningkatkan atau menurunkan variabel yang ingin diubah. Sementara itu ada 2 penelitian yang memiliki hasil yang negatif yakni penelitian yang berkaitan dengan membandingkan pengaruh well-being therapy dengan positive therapy terhadap sikap penggunaan obat pada pasien yang mengalami ketergantungan zat metadon. Dalam penelitian tersebut tidak ditemukan perbedaan yang signifikan antara keduanya namun ternyata memberikan pengaruh yang positif jika dibandingkan dengan kelompok kontrol yang tidak diberikan perlakuan sama sekali. Pirnia (2015) menjelaskan bahwa hal ini dapat disebabkan baik well-being therapy maupun positive therapy sama-sama memiliki dasar intervensi yang sama 
yakni sama-sama menggunakan pendekatan kognitif dan perilaku yang mana pendekatan ini sebelumnya sudah banyak digunakan untuk mengatasi perilaku bermasalah pasien berkaitan dengan ketergantungan pada zat tertentu. Kedua perlakuan sama-sama memiliki efek meningkatkan emosi positif yang dapat mengubah sikap pasien terhadap obat.

Pada penelitian lainnya berkaitan dengan efektivitas well- being therapy terhadap kesehatan mental, psikopatologis dan kebahagiaan, Pirnia et al. (2016) menjelaskan tidak signifikannya hasil yang didapatkan disebabkan oleh faktor waktu pengukuran pretest (dilakukan pada honeymoon phase) sementara pengukuran posttest dilakukan pada wall stage yang merupakan tahap partisipan sudah mengalami kehilangan energi, kelelahan, dan ketidakmampuan merasakan kesenangan. Alasan lain adalah kerusakan memori jangka pendek dari partisipan. Hal ini menunjukkan bahwa kerusakan pada memori dapat memengaruhi efektivitas well-being therapy mengingat well-being therapy memiliki pendekatan kognitif.

Hasil ulasan menunjukan well-being therapy dapat diterapkan pada usia anak-anak (8 tahun) hingga dewasa. Pada usia anak dan remaja, well-being therapy diterapkan sebagai upaya preventif dalam menurunkan kecemasan dalam menjalani peristiwa penuh stres di masa anak-anak sehingga anak dan remaja lebih mampu beradaptasi dengan tahap perkembangan yang sedang dijalani. Hal ini sejalan dengan peran sekolah yang tidak hanya mendidik pelajar dalam hal kecerdasan intelektual saja namun juga membangun pelajar yang memiliki kemampuan sosial, pemecahan masalah, serta perilaku adaptasi (Ruini et al., 2006). Penelitian Ruini tersebut menunjukkan bahwa well-being therapy membantu mencegah individu mengalami distres dan psikopatologis seperti kecemasan dan depresi serta meningkatkan keberfungsian individu secara optimal terutama dalam regulasi emosi berkaitan dengan peristiwa stres yang dialami selama masa anak dan remaja. Hal lain adalah bahwa melalui well-being therapy individu diminta untuk melaporkan pengalaman kehidupan yang dialami dengan tidak memperhatikan usia sehingga lebih berfokus pada pengalaman kehidupan tidak peduli apakah ceritanya banyak atau sedikit (Ruini \& Fava, 2015). 
Berdasarkan konteks permasalahan dari partisipan yang mengikuti wellbeing therapy didapatkan bahwa well-being therapy dapat diterapkan untuk penanganan gangguan kecemasan, gangguan afek, permasalahan adiksi terhadap zat tertentu, promosi kesejahteraan dalam upaya pencegahan gangguan kecemasan dan gangguan afek pada anak sekolah (Ruini \& Fava, 2015). Hal ini pun tak terlepas kaitannya dengan tujuan dari penelitian yang diberikan baik usaha preventif maupun kuratif memiliki hasil yang signifikan melalui pemberian intervensi well-being therapy. Hal ini sejalan dengan Ruini (2009) bahwa wellbeing therapy mendorong pasien untuk mencari dan terlibat dalam pengalaman kehidupannya secara optimal dan mencari alternatif kegiatan yang dapat menyenangkan bagi individu tersebut sehingga lebih dapat merasakan perasaan sejahtera. Fava (2016) menambahkan bahwa melalui well-being therapy dapat memperbaharui ketahanan individu dalam berbagai kondisi kejiwaan dan medis, memodulasi kesejahteraan psikologis dan suasana hati, mengembangkan pilihan alternatif untuk pengobatan yang sedang dijalani termasuk obat-obatan psikotropika.

Hal lain adalah bahwa jumlah sesi dari pelaksanaan intervensi memiliki pengaruh yang berbeda-beda. Jumlah sesi yang banyak tidak menentukan keberhasilan dari intervensi yang diberikan seperti pada penanganan gejala psikopatologi dan peningkatan kebahagiaan dalam penelitian Pirnia (2016). Penekanan penting berdasarkan struktur dari well-being therapy yakni well-being therapy merupakan sebuah strategi psikoterapi jangka pendek berdasarkan model kesejahteraan psikologis dari Ryff yang terdiri dari tiga tahapan yakni tahap pembuka, tahap pertengahan dan tahap akhir (Ruini, Albieri \& Vescovelli , 2014) Tahap-tahap ini harus dapat dilewati oleh individu dan setiap tahapan tidak ditentukan berapa jumlah sesinya tergantung pada motivasi dan kemampuan individu dalam menemukan strategi yang dapat dilakukan untuk meningkatkan kesejahteraan dirinya sendiri (Ruini \& Fava, 2015).

Penggunaan dua atau lebih intervensi sekaligus secara berurutan pada kasus tertentu menghasilkan signifikansi pada hasil penelitian seperti pada penelitian yang dilakukan Fava et al. (2005), Fava et al. (2011), Kennard et al. 
(2014) dan Stangier et al. (2013) yang memadukan well-being therapy dengan cognitive behavior therapy serta medication management. Penting untuk diketahui bahwa cognitive behavior therapy dan well-being therapy memiliki fokus yang berbeda. Cognitive behavir therapy berfokus pada tekanan psikologis yang dialami oleh individu sementara well-being therapy memfokuskan pada perasaan sejahtera. Perbedaan lainnya adalah cognitive behavior therapy bertujuan untuk menurunkan tekanan psikologis yang dialami dengan melakukan kontrol terhadap pikiran otomatis yang sering muncul sementara well-being therapy bertujuan meningkatkan keberfungsian diri secara optimal (Ruini \& Fava, 2015). Penggunaan dua terapi secara berurutan dapat dikatakan dapat mengarah pada identifikasi pikiran otomatis yang dimiliki individu yang lebih komprehensif dibandingkan hanya menggunakan terapi kognitif saja sehingga lebih dapat menghasilkan restrukturisasi kognitif yang lebih efektif. Kedua teknik ini dapat saling memadukan dalam mengubah keyakinan dan sikap yang dimiliki individu sebelumnya yang dapat mengganggu perasaan well-being kemudian dilanjutkan dengan usaha untuk merangsang pertumbuhan pribadi secara optimal dan mengembangkan perasaan well-being (Ruini, 2009).

\section{Kesimpulan dan Saran}

\section{Kesimpulan}

Well-being therapy dapat diterapkan pada berbagai kelompok usia sebagai upaya preventif dalam meningkatkan kesejahteraan individu maupun penanganan kuratif dalam menyelesaikan permasalahan yang dialami individu. Adapun permasalahan yang sudah ditangani menggunakan intervensi well-being therapy, yakni gangguan kecemasan, gangguan afek, permasalahan ketergantungan zat, dan peningkatan well-being. Well-being therapy dapat dipadukan dengan cognitive behavior therapy untuk menunjang hasil terapeutik yang lebih signifikan.

\section{Saran}

Dalam ulasan ini hanya terdapat sedikit tipe kasus serta beberapa penelitian berasal dari beberapa penulis saja sehingga ulasan ini kurang memiliki 
banyak informasi mengenai efektivitas pada kasus lain dan juga pelaksanaan intervensi dari peneliti lain sehingga perlu melakukan pencarian sumber penelitian lain untuk memperkaya sumber data.

\section{DAFTAR PUSTAKA}

Fava, et al. (2001). Psychological well-being and residual symptoms in remitted patients with panic disorder and agoraphobia. Journal of Affective Disorders, 31, 899-905.

Fava, et al. (2005). Well-being therapy of generalized anxiety disorder. Psychother Psychosom, 74, 26-30.

Fava, et al. (2011). The sequential combination of cognitive behavioral treatment and well-being therapy in cyclothimic disorder. Psychoter Psychosom, 80, 136-143.

Fava, G. A. (1999). Well-being therapy: Conceptual and technical issues.Psychother Psychosom, 68, 171-179.

Fava, G. A. (2016). Well-being therapy: Current indications and emerging perspectives. Psychoter Psychosom, 85, 136-145.

Guidi, J., Rafanelli, C., \& Fava, G. A. (2018). The clinical role of well-being therapy. Nordic Journal of Psychiatry, 1-7.

Kennard, et al. (2014). Sequential treatment with fluoxetine and relapse prevention CBT to improve outcomes in pediatric depression. Am J Psychiatry, 171(10), 1083-1090.

Moeenizadeh, M., \& Salagame, K. K. (2010). The impact of well-being therapy on symptom of depression. International Journal of Psychological Studies, 2(2), 223-230.

Moeenizadeh, M., \& Salagame, K. K. (2010). Well-being therapy (WBT) for depression. International Journal of Psychological Studies, 2(1), 107- 115.

Moeenizadeh, M., \& Zarif, H. (2017). The efficacy of well-being therapy for depression in infertile women. International Journal of Fertility and Sterility, 10(4), 363-370.

Pirnia, B. (2015). The effectiveness of group positive-therapy (PPT) and wellbeing therapy (WBT) on attitude towards drug abuse in patients under methadone maintenace therapy. World Journal of Medical Science, 12(4), 
354-360.

Pirnia, B., Rezayi, A., \& Rahimian E. (2015). The effectiveness of group wellbeing therapy on depression, anxiety, and stress (DAS) indices in men and women dependent to methamphetamine. International Journal of Biology, Pharmacy and Allied Sciences, 4(6), 3887-3902.

Pirnia, B., Azemnia, Z., \& Soleimani, A. A. (2016). Psychotherapy and condom use, effectiveness of well-being therapy (WBT) on condom-use skills in cocaine-dependent. Imperial Journal of Interdisciplinary Research, 2(6), 1229-1236.

Pirnia, B., Rezaei, A. M., Boogar, E. R., \& Soleimani, A. (2016). On the effectiveness of well-being therapy in mental health, psychopatology, and happiness in methamphetamine dependent men. Research on Addiction Quarterly Journal of Drug Abuse, 10(37), 167-177.

Ruini, C. (2014). The use of well-being therapy in clinical settings. The Journal of Happiness \& Well-Being, 2(1), 75-84.

Ruini, C., Albieri, C., \& Vescovelli, F. (2014). Well-being therapy: State of art and clinical exemplifications. J Contemp Psychoter.

Ruini, C. \& Fava, G. A. (2015). Clinical applications of well-being therapy. Dalam A. D. Fave (Ed). Increasing psychological wellbeing in clinical and educational settings. New York: Springer.

Ruini, et al. (2006). Well-being therapy in school settings: a pilot study. Psychoter Psychosom, 75, 331-336.

Ruini, et al. (2009). School intervention for promoting psychological well-being in adolescence. Journal of Behavior Therapy and Experimental Psychiatry, $40,522-532$.

Ryff, C. D. (1989). Happiness is everything, or is it? Explorations on the meaning of psychological well-being. Journal of Personality \& Social Psychology, 6, 1069-1081.

Stangier, et al. (2013). Maintenance cognitive behavioral therapy and manualized psychoeducation in the treatment of recurrent depression: A multicenter prospective randomized controlled trial. Am J Psychiatry, 170(6), 624- 632.

Tomba, et al. (2010). Differential effects of well-being promoting and anxietymanagement strategies in a non-clinical school setting. Journal of Anxiety Disorders, 24, 326-333. 